\title{
Microdontia treatment with orthodontics and indirect restoration: clinical case
}

\author{
Tratamento da microdontia com ortodontia e restauração indireta: caso clínico \\ Tratamiento de microdoncia con ortodoncia y restauración indirecta: caso clínico \\ Sávio Morato de Lacerda GONTIJO \\ Laura Costa GONÇALVES \\ Fernanda Novais ARANTES \\ Francisca Daniele Jardilino SILAMI \\ João Batista NOVAES JÚNIOR \\ Ivan Doche BARREIROS \\ Department of Oral Surgery, Pathology and Clinical Dentistry, Faculty of Dentistry, Federal University of Minas Gerais, \\ 31270-901 Belo Horizonte-MG, Brazil
}

\begin{abstract}
Objective: This case report aims to present the microdontia treatment of tooth 35 through pre-prosthetic orthodontics, followed by re-anatomization with an indirect restoration. Case report: A 21 -year-old female patient presented with microdontia in tooth 35 , with a distalized and vestibularized crown. In addition, tooth 34 was gyroverted with mesial diastema. Orthodontic mechanics with segmented arch were used to centralize tooth 35 in the alveolar ridge, close the diastema in the mesial of tooth 34 , and correct its gyroversion. For lingualization of tooth 35, a first-order fold (in set) was performed, and for mesialization, an open-coil spring was used between teeth 35 and 36. A closed-coil spring was used to delimit the movement of tooth 35 to mesial. The force applied by the open spring for mesialization of tooth 35 was transmitted to tooth 34 , through the closed spring, resulting in its mesialization; this, closed the diastema between teeth 33 and 34 and corrected the gyroversion. Subsequently, the coronary preparation was performed with diamond tips 1014 and 3146, and confection of the temporary crown in acrylic resin. For the ceramic system, IPS ${ }^{\mathrm{TM}}$ e.max Press was used. The ceramic crown was luting using the adhesive technique, followed by light curing for 40 seconds on each face of the tooth. Conclusion: It can be concluded that the re-anatomization of a small tooth should be the first treatment option. However, pre-prosthetic orthodontic treatment may be necessary.

Descriptors: Microdontia; Pre-Prosthetic Orthodontic Treatment; Ceramic; Indirect Restoration.

Resumo

Objetivo: Este relato de caso tem como objetivo apresentar o tratamento da microdontia do dente 35 por meio da ortodontia pré-protética, seguido pela reanatomização com uma restauração indireta. Relato de caso: paciente do sexo feminino, 21 anos, apresentava microdontia no dente 35 , com coroa distalizada e vestibularizada. Além disso, o dente 34 estava girovertido com diastema na mesial. A mecânica ortodôntica com arco segmentado foi utilizada para centralizar o dente 35 no rebordo alveolar, fechar o diastema na mesial do dente 34 e corrigir sua giroversão. Para a lingualização do dente 35 , foi realizada uma dobra de primeira ordem (in set) no arco e, para a mesialização, foi utilizada uma mola helicoidal aberta entre os dentes 35 e 36 . Uma mola helicoidal fechada foi utilizada para delimitar o movimento do dente 35 para mesial. A força aplicada pela mola aberta para mesialização do dente 35 foi transmitida ao dente 34 , através da mola fechada, resultando em sua mesialização; isto, fechou o diastema entre os dentes 33 e 34 e corrigiu a giroversão. Posteriormente, foi realizado o preparo coronário com pontas diamantadas 1014 e 3146 e confecção da coroa provisória em resina acrílica. Para o sistema cerâmico, foi utilizado o IPS ${ }^{\mathrm{TM}}$ e.max Press. A coroa de cerâmica foi cimentada pela técnica adesiva, seguida de fotopolimerização por 40 segundos em cada face do dente. Conclusão: Pode-se concluir que a reanatomização de um microdente deve ser a primeira opção de tratamento. No entanto, o tratamento ortodôntico pré-protético pode ser necessário.
\end{abstract}

Descritores: Microdontia; Tratamento Ortodôntico Pré-Protético; Cerâmica; Restauração Indireta.

Resumen

Objetivo: Este caso clínico tiene como objetivo presentar el tratamiento de la microdoncia del diente 35 mediante ortodoncia preprotésica, seguida de reanimación con restauración indirecta. Caso clínico: paciente de 21 años con microdoncia en el diente 35 , con corona distalizada y vestibular. Además, el diente 34 estaba girovertido con un diastema mesial. Se utilizó una mecánica de ortodoncia con arco segmentado para centrar el diente 35 en el reborde alveolar, cerrar el diastema en mesial del diente 34 y corregir su giroversión. Para la lingualización del diente 35 se realizó un pliegue de primer orden (in set) en la arcada y, para la mesialización, se utilizó un resorte helicoidal abierto entre los dientes 35 y 36 . Se utilizó un resorte helicoidal cerrado para delimitar el movimiento del diente 35 para mesial. La fuerza aplicada por el resorte abierto para la mesialización del diente 35, fue transmitida al diente 34, a través del resorte cerrado, resultando en su mesialización; esto, cerró el diastema entre los dientes 33 y 34 y corrigió la giroversión. Posteriormente, se realizó la preparación coronaria con puntas de diamante 1014 y 3146 y la corona provisional se realizó en resina acrílica. Para el sistema cerámico se utilizó IPS TM e.max Press. La corona de cerámica se cementó mediante la técnica adhesiva, seguida de fotopolimerización durante 40 segundos en cada cara del diente. Conclusión: Se puede concluir que la reanimación de un microdent debe ser la primera opción de tratamiento. Sin embargo, puede ser necesario un tratamiento de ortodoncia preprotésico.

Descriptores: Microdoncia; Tratamiento de Ortodoncia Preprotésica; Cerámica; Restauración Indirecta.

INTRODUCTION

Dental microdontia is an anomaly in which the teeth are smaller than normal and may be generalized or localized ${ }^{1-3}$. Localized microdontia, on a single tooth, is the most common form and may involve the crown and/or the root ${ }^{1}$. The lateral incisors and the third molars are the teeth most frequently affected, with microdontia being rare in the lower second premolars $^{1,2}$. In addition to their reduced size, these teeth often have other associated congenital anomalies ${ }^{2-4}$.

Size anomalies are believed to arise during dental development, in the morphogenesis phase. The etiology of microdontia is multifactorial, involving genetic and environmental factors ${ }^{5}$. Among the causes of this anomaly, trauma and radiation in the jaws during dental development can be mentioned ${ }^{2-4}$.

The presence of a small tooth can result in diastemas and occlusal problems ${ }^{2,6,7}$. Interproximal contact protects the interdental gingiva from the impacts caused by chewing, which is essential for maintaining periodontal health $^{6,8}$. The change in the shape of the crown 
and/or the position of a small teeth may result in occlusal instability, due to the lack of intercuspation of the functional cusps in the antagonistic fossae ${ }^{7}$.

One of the options for the treatment of a small tooth is tooth include extraction, followed by the placement of an implant or a fixed prosthesis $^{9}$. This option is indicated when the small tooth shows a reduction in the size and width of the root, being unable to resist occlusal forces $^{9,10}$

Another treatment option would be the direct or indirect restoration of the tooth in question when the remaining tooth is able to resist occlusal forces after esthetics and reestablishment of function ${ }^{3,11}$. The direct restoration in composite resin results in the polymerization contraction inherent in the curing reaction of the material. This tension generated by the polymerization of the material can result in the appearance of cracks and can compromise the marginal sealing ${ }^{12,13}$. In addition, direct restoration shows instability in relation to color change and risk of staining ${ }^{14}$. Therefore, the present study opted for the reanatomization of tooth 35 through the use of an indirect restoration.

The aim of this study was to return the shape, function, and esthetics of the smile to the patient through the centralization of tooth 35 in the center of the alveolar ridge and reanatomization with a metal-free full crown.

\section{CLINICAL CASE}

The patient was a 21-year-old female, complaining of tooth 35 morphology and discomfort in the gingival soft tissue, during chewing, due to the lack of interproximal contact in teeth 34 and 35. After the clinical examination, was observed the presence of a diastema in the mesial and distal of tooth 34, and that tooth 35 had microdontia with a conoid shape. Tooth 34 also presented with gyroversion (Figure 1). All procedures were conducted following informed consent.

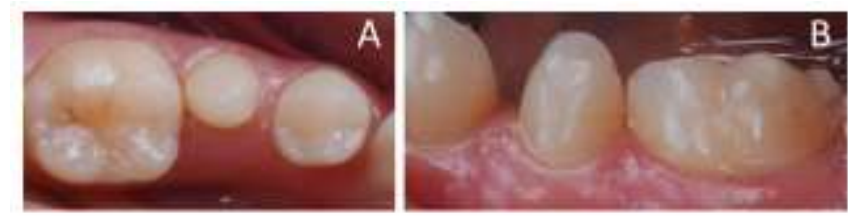

Figure 1: Initial clinical case. (A) occlusal view; (B) front view.

To restore the shape and function of tooth 35 , a full crown was initially proposed. However, it would be necessary to centralize the tooth in the arch, because the crown was in a vestibularized and distalized position (Figure 1).

For the centralization of tooth 35 in the dental arch, segmented arch mechanic was used. For this, brackets were bonded (prescription
Edgewise, slot 0.022 " $\times 0.025$ ") from tooth 33 to tooth 37. A 0.020 " stainless steel wire was passively inserted into teeth $33,34,36$, and 37 for anchoring orthodontic tooth movement. For lingualization of tooth 35, a first-order fold (in set) was performed, and for mesialization, a nickel-titanium open-coil spring was used between teeth 35 and 36 (Figure 2).

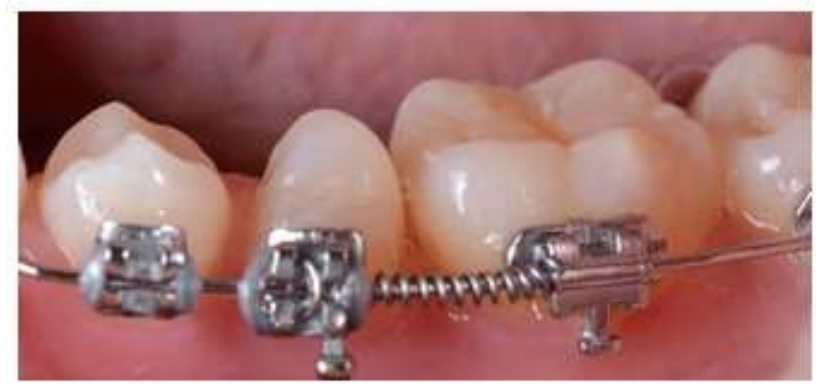

Figure 2: Segmented arch mechanics.

To avoid excessive movement of tooth 35 to mesial, a stainless-steel closed-coil spring was subsequently used between teeth 34 and 35. The force applied by the open spring for mesialization of tooth 35 was transmitted to tooth 34 through the closed spring, resulting in its mesialization and closing of the diastema between teeth 33 and 34 . In addition, the resulting force on tooth 34 corrected its gyroversion, with the mesial inward rotation and the distal outward rotation.

After the centralization of the clinical crown of tooth 35 in the alveolar ridge, prophylaxis with Robson's brush and pumice (Kerr Corporation, Orange, CA, USA) was performed, followed by cavity preparation with diamond tips 1014 and 3146. Subsequent confection of the temporary crown was done in acrylic resin (JET, Classic, São Paulo, SP, Brazil) (Figure 3).

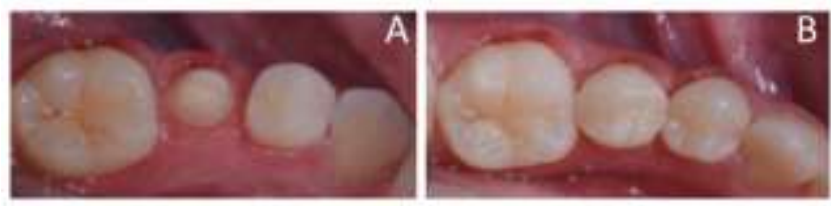

Figure 3: $(A)$ occlusal view after centralization of tooth 35 in the alveolar ridge and cavity preparation, and (B) after luting of the temporary crown.

To make the ceramic crown, the cavity preparation was first molded with individual acrylic copings and polyether (Impregum ${ }^{\mathrm{TM}}, 3 \mathrm{M}$ ESPE, Saint Paul, MN, USA) to obtain the master die. To obtain the cast for assembly in the verticulator, the triple tray (3D MOLDEX, Angelus, Londrina, Paraná, Brazil) and addition silicone (V Posil Fast, VOCO, Indian Land, SC, USA) were used. The molding was carried out in a double-mix impression. An artificial gingiva (Gingifast, Zhermack, Badia Polesine, RO, Italy) was added to the mold to copy the gingival space. Plaster type IV dental stone (Durone IV, 
Dentsply Sirona, York, PA, USA) was used to obtain the master die and the working cast.

The chosen ceramic system was IPS ${ }^{\mathrm{TM}}$ e.max Press, a lithium disilicate-based glass. The selected color was A2 (Vitapan Classical ${ }^{\circledR}$ Shade Guide, Bad Säckingen, Germany). Previously, the luting of the crown was checked for marginal adaptation, with a No. 5 explorer probe, and the occlusal and interproximal contacts were assessed with carbon paper (AccuFilm, Parkell, Edgewood, NY, USA). The ceramic crown was then luted using the adhesive technique (RelyX ${ }^{\mathrm{TM}}$ U200, 3M ESPE, Saint Paul, MN, USA) and light cured for 40s on each tooth face. Figure 4 shows the final result.

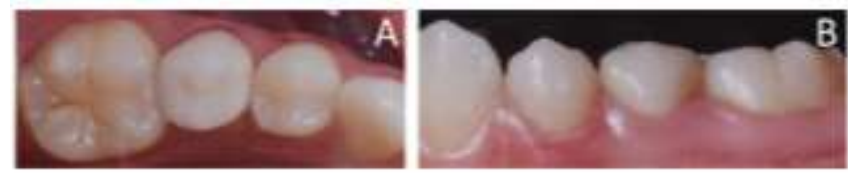

Figure 4: Final result after permanent crown luting. (A) occlusal view; (B) front view.

DISCUSSION

The extraction of tooth 35 followed by the placement of an implant was discarded, because the size and width of the root they were able to withstand occlusal forces.

In a restorative planning, the element that will receive the restoration must be analyzed, taking into account the dental anatomy and its position in the arch. During this observation, the need for orthodontic treatment was perceived before evolving to the restorative part.

Orthodontic treatment was necessary for the centralization of tooth 35 in the alveolar ridge and for a better distribution of occlusal forces after re-anatomization. In addition, orthodontic treatment would contribute to the closure of the diastema between the first premolar and the canine, and the correction of the gyroversion of the first premolar. This happened due to the force that the open-coil spring exerted on the conoid tooth, which displaced it to the mesial. From the moment that tooth 35 touched the closed spring, this force started to be transmitted to the first premolar, correcting the gyroversion and closing the diastema.

For the re-anatomization of tooth 35 with direct composite resin, the use of a large amount of restorative material would be necessary, resulting in a greater polymerization contraction, which could reduce the survival of the restoration ${ }^{13}$.

The choice of a full metallic crown for the re-anatomization of tooth 35 was excluded by the patient, due to esthetic requirements.

Metal-ceramic crowns and IPS ${ }^{\mathrm{TM}}$ e.max Press crowns have similar survival rates on posterior teeth $^{15}$. However, a metal-ceramic crown would require a larger clinical crown in the occlusal-apical direction, which would result in wear on the adjacent bone ridges, damaging the neighboring teeth. Therefore, the choice was made for a metal-free crown.

The IPS ${ }^{\mathrm{TM}}$ e.max Press is indicated for posterior full crowns and has better mechanical properties, durability, esthetics, and translucency when compared to other vitreous systems such as the leucite-reinforced IPS Empress $^{16}$.

For luting of the full crown, the adhesive technique was chosen because the preparation on tooth 35 is not very retentive. Adhesive luting is made with resin cements which adhere to metallic, resinous structures and porcelain ${ }^{17}$. In addition, resin cements have excellent mechanical properties with low solubility ${ }^{17,18}$. CONCLUSION

It can be concluded that, whenever possible, one should opt for a restorative treatment of a conoid tooth in relation to an extraction. The restorative treatment allows the reestablishment of esthetics and function. However, in many situations pre-prosthetic orthodontic treatment is necessary.

REFERENCES

1. Ufomata D. Microdontia of a mandibular second premolar. Oral surg oral med oral pathol. 1988;655:637-38 .

2. Kaste SC, Hopkins KP, Jones D, Crom D, Greenwald CA, Santana VM. Dental abnormalities in children treated for acute lymphoblastic leukemia. Leukemia.1997;11(6): 792-96.

3. Pegoraro LF, Do Valle AL, Pegoraro TA, Corotti KMV, Vidotti HA. Resolution of complex esthetic problems in abnormal anterior teeth: $A$ clinical report. J Prosthet Dent. 2014;112(2): 94-8.

4. Pedersen LB, Clausen N, Schrøder H, Schmidt M, Poulsen S. Microdontia and hypodontia of premolars and permanent molars in childhood cancer survivors after chemotherapy. Int $\mathrm{J}$ Paediatr Dent. 2012;22(4):239-43.

5. Brook A, Jernvall $J$, Smith $R$, Hughes $T$, Townsend G. The dentition: the outcomes of morphogenesis leading to variations of tooth number, size and shape. Aust Dent J. 2014;59(Suppl 1):131-42.

6. De Freitas Brianezzi LF, Brondino BM, De Campo Chaves G, Ishikiriama SK, Furuse AY. Interdental papilla formation after diastema closure. Gen Dent. 2017;65(6):e13.

7. Yassin SM. Prevalence and distribution of selected dental anomalies among saudi children in Abha, Saudi Arabia. J Clin Exp Dent. 2016;8(5):e485-90. 
8. Saratti CM, Krejci I, Rocca GT. Multiple diastema closure in periodontally compromised teeth: How to achieve an enamel-like emergence profile. J Prosthet Dent. 2016;116(5):642-46.

9. Nihill P, Lin LY, Salzmann LB, Stevens S. Esthetic overdenture for a patient with possible Seckel syndrome. Spec Care Dent. 1996;16(5):210-13.

10. Morkmued S, Clauss F, Schuhbaur B, Fraulob $V$, Mathieu $E$, Hemmerlé $J$ et al. Deficiency of the SMOC2 matricellular protein impairs bone healing and produces age-dependent bone loss. Sci Rep. 2020;10(1):14817.

11. Patroni S, Cocconi R. From orthodontic treatment plan to ultrathin no-prep CAD/CAM temporary veneers. Int J Esthet Dent. 2017; 12(4):504-22.

12. Meshram P, Meshram V, Palve D, Patil S, Gade V, Raut A. Comparative evaluation of microleakage around Class $\mathrm{V}$ cavities restored with alkasite restorative material with and without bonding agent and flowable composite resin: An in vitro study. Indian J Dent Res. 2019;30(3):403-7.

13. Kleverlaan CJ, Feilzer AJ. Polymerization shrinkage and contraction stress of dental resin composites. Dent Mater. 2005;21(12):1150-57.

14. Heintze SD, Rousson V, Hickel R. Clinical effectiveness of direct anterior restorations - A meta-analysis. Dent Mater. 2015;31(5):481-95.

15. Etman MK, Woolford MJ. Three-year clinical evaluation of two ceramic crown systems: A preliminary study. J Prosthet Dent. 2010; 103(2):80-90.

16. Heintze SD, Albrecht T, Cavalleri A, Steiner M. A new method to test the fracture probability of all-ceramic crowns with a dual-axis chewing simulator. Dent Mater 2011;27(2):e10-9.

17. Manso AP, Carvalho RM. Dental Cements for Luting and Bonding Restorations: Self-Adhesive Resin Cements. Vol. 61, Dent Clin North Am.2017;61(4):821-34.

18. Yoshida K, Tanagawa M, Atsuta M. In-vitro solubility of three types of resin and conventional luting cements. J Oral Rehabil. 1998;25(4):285-91.

\section{CONFLICTS OF INTERESTS}

The authors declare no conflicts of interests.

\section{CORRESPONDING AUTHOR}

\author{
Sávio Morato de Lacerda Gontijo \\ Department of Oral Surgery, \\ Pathology and Clinical Dentistry, \\ Faculty of Dentistry, \\ Federal University of Minas Gerais (UFMG), \\ Av. Presidente Antônio Carlos 6627, \\ 31270-901, Belo Horizonte - MG, Brazil \\ Tel: +55 31-3409-2427, Fax: +55 31-3409-2427 \\ E-mail: savio.morato@yahoo.com.br
}

